\title{
Customer experience in the process of e-banking service recovery through the moderation role of customer personality
}

\author{
Badawi \\ Wiwi Hartati \\ Management Department \\ Universitas Muhammadiyah Cirebon, Indonesia \\ Errie Margery \\ Management Department \\ STIE Professional Manajemen College Indonesia, Medan, Indonesia \\ Pawana Nur Indah \\ Agribusiness Departement \\ Universitas Pembangunan Nasional “Veteran” Jatim, Indonesia
}

\author{
Keywords \\ Customer's Prior Experience, Interactional Justice, Procedural Justice, and Customer Personality
}

\begin{abstract}
This research tests and analyse the influence of customer's prior experience toward procedural justice and interactional justice perceived by customer toward the process of service recovery through the moderation role of customer personality in the e-banking service on three state-owned banks in West Java, Indonesia. The respondent of this research is e-banking customer in three banks (BRI, BNI, and BTN) in West Java, Indonesia with 300 respondents. The analysis technique that is used is Structural Equation Modeling (SEM). The research result proves that: (1) there is a positive and significant influence of customer's prior experience toward interactional and procedural justice, (2) customer's experience moderates the influence of customer's prior experience toward interactional and procedural justice. This research result provides theoretical contribution toward the development model of customer's prior experience in the process of service recovery on e-banking service with the moderation variable of customer personality. Besides, this research finding is also useful for e-banking service in Indonesia as a strategy to decide service recovery that provides sense of justice as the key to customer satisfaction.
\end{abstract}

Corresponding author: Badawi

Email addresses for the corresponding author: badawiumc2018@gmail.com

First submission received: $8^{\text {th }}$ October 2018

Revised submission received: $6^{\text {th }}$ December 2018

Accepted: 14 $4^{\text {th }}$ December 2018

\section{Introduction}

The role of information technology on banking industry services is a banking system supported by information technology. The growing and complexity of the facility applied can provide ease of service for customers (Muafi., Suwitho., Purwohandoko., and Salsabil, 2017). Currenly, almost all products in the banking fincance industry use information technology. This has an impact on the high competition with various services. Banking service industry has a high level of involvement between customer and employee. This does not close the possibility of errors or failures in the service and efforts to meet the expectations of all customers (Badawi, Tjahjono \& Muafi, 2017). Service failure occurs when customer's expectation is not met by the company or service provider (Sholeh, 2014). No matter how good the services the company gives to its customers, there is still the possibility of companies making mistakes in meeting the expectations of customers who tend to be more demanding; and then reduce their loyalty (Nikbin., Ismail., \& Marimuthu. 2010). Service failures generate dissatisfaction and lead to customer losses (Chelminski\& Coulter, 2011) such as the disconnected relationship of customer with the company, brandswitching, and negative word-of-mouth recommendation (Andreassen, 2000). Customer personality traits are a basis to understand a number of differences in customer behavior (Adams. 2001).Several prior 
researches have stated that there is a relationship between personality and emotion (Gountas \& Gountas, 2007).The research result from Lin (2009); Parasuraman, Zeithaml, and Berry (1996) explains that postpurchase satisfaction is helpful to strengthen consumer confidence and preferences toward the products and services that they buy and reinforce their repurchase intention (Lin, 2009). This means that consumer behaviour intentions are usually affected by their purchasing experience and emotional response (Parasuraman et al., 1996; Singh \& Wilkes, 1996; Singh, 1990; Fornell \& Wernerfelt, 1988).

Personality research in the justice research in the field of human resources and marketing has been researched, for example in hostile environment and neuroticism that moderate the relationship between the perception of justice and absenteeism (Elovainio et al., 2003). The research that is conducted by Aquino, Lewis, and Bradfield, (1999) in the justice perception and effectiveness has a negative influence on behavioural deviation. Martocchio \&Judge (1995) examines the personality traits associated with justice in slightly different way, by knowing and explaining stable personality traits that influence the different ways of decision making between supervisors and employees at the level of discipline. The research from Lin (2009) states that personality trait is a model that influence the factor of customer's postpurchasing behaviour with external self-control character. It is done by showing low self-awareness and self-confidence, and it can be influenced by external environment such as advertising media. Whereas, customers with internal self-control characters tend to collect information internally and externally to find a difference; and they do not show reaction or desire behaviour in a sudden. Customer personality traits are other factors that influence post-behavioural intentions toward related products or services (Todd \& Olver, 1997; Engel, Blackwell, \& Miniard, 1993). Although the perceived justice provided by the organization has been shown to have consequences on behaviour, there are some variables that explain how personality reacts to fair treatment and injustice (Lin, 2009). The research from Shin, Casidy, and Mattila (2018) examined the influence of service recovery toward customers'attutude and behavior reaction that are different with professional service in the US The research result explains that distributive justice provides thehighest contribution compared to the response for apologyfrom the service provider to customers.

Customer's previous experience continually renewed their beliefs and expectations on some form of service and integrated new information with prior knowledge. Woodruff, Ernest., and Roger (1983) states that expectations are normative based on experience of goods or products. Zeithaml et al. (1990) adds that there is a diverse expectation from each customer, which is formed from past experience along with word of mouth recommendations and advertisements about the company. Thus, recovery management can be considered to have an impact on customer evaluation, as customers are accustomed to involve their feelings or emotion in the process of service recovery, and they can be increasingly unsatisfied if the company's recovery efforts fail (Bitner, Booms, and Tetreault, 1990; Berry dan Parasuraman, 1991). Tax et al. (1998) identifies customer's prior experience as an important component in service experience, because it affects subsequent service experience and the relationship between customer and service provider in the future. Whereas, Clemmer and Schneider (1996) states that service recovery leads to the aspect of process and relationship in service recovery as well as outputs. Therefore, according to McDougall and Levesque (2000) what the company has done and how it is done will affect the customer's perception of justice. Previous research has proved that there are substantial differences in personality relationship with performance result that remain unexplained (Barrick, Parks, \& Mount. 2005, Hogan, 2003; Nikolaou \& Robertson, 2001). Barrick et al. (2005), states that personality and situational condition will mediate the influence of personality traits toward service recovery performance. Organ (1990) also suggests that personality can have indirect influence toward service recovery performance through personality. Lewin (1951) suggests that individual behaviour is a function of the environment. Some researchers have focused on prior experience in the context of service recovery of information technology toward procedural and interactional justice that are perceived to be lacking much less connected to the moderation of customer's personality; which can explain various reactions to perceived justice (Colquitt, Greenberg, \& Zapata-Phelan 2005: Colquitt., 2001: Lind, 2001; Van \& Bos, 2001; Badawi, et al., 2017). This research attempts to narrow the gap in the literature of personality traits by examining the relationship of personality as moderation between customer, perceived procedural justice, and perceived interactional justice (Colquitt, Scott, Judge, \& Shaw. 2006). This research is conducted in three 
large state-owned banks in the Province of West Java, especially customers who use e-banking. This is because some customers still have the perception that they do not have a satisfactory channel with fair procedural and interactional about e-banking problems that happened to them.

\section{Literature review}

\section{Customer's Prior Experience and Interactional Justice on Service Recovery}

Mossberg (2007) defines that customer's prior experience is a mixture of elements that involve consumer emotionally, physically, intellectually, and spiritually as a whole. Hess et al. (2003; Tax et al., 1998; Kelley \& Davis, 1994) explains about quality evaluation perceived from past service performance. Oh and Parks (1997) states that prior experience is the relationship between customer and business through the assessment of service quality comparison with the level of customer satisfaction. Interactional justice according to Tax et al. (1998), is a procedure that has been established in service improvement process. The measure that is used in this research is the basis shown by individual to the company such as empathy, attention to problem solving, and willingness to explain why complaints occur (Tax et al., 1998; Blodgett, Hill., \& Tax, 1997). Interactional justice is also a part of equity in the company's response as a reward and resources. Interactional justice is also related with communication aspect between company and customer such as politeness, honesty, and respect (Tyler \& Bies, 1990; Bies \& Moag, 1986). The study from Yuan\& $\mathrm{Wu}(2008)$ explains that customer's prior experience has an influence toward satisfaction and loyalty through emotional and functional values. Oh, Fiore, and Jeoung. (2007) adds that the four dimensions of experience in face and nomolical validity research can be a starting point to measure the concept of experience and practice in lodging (hotel) and tourism settings. Mattila and Wirtz (2006) find that the perceived appearance of an attractive environment can cause displeasure when it was led with relationship simulation between emotion and desire. Some empirical researches examines the concept of interactional justice in the marketing concept that describe interpersonal justice treatment contributing to service satisfaction (Bitner et al., 1990; Tyler, 1987), improvement of service quality evaluation, (Parasuraman et al., 1985), evaluation of all complaint handling, (Goodwin and Ross, 1992) and willingness to repurchase (Blodgett and Tax, 1993). Badawi (2012) finds that interactional justice can increase satisfaction over complaints handling.

H1: Customer's prior experience can provide a sense of procedural justice in the process of service recovery.

\section{Customer's Prior Experience and Procedural Justice on Service Recovery}

Perceived characteristic procedure can be identified with work, evaluation, two-way communication, and compliance (Bauer, Morrison., \& Calliste., 1998; Ryan \& Chan, 1999; Truxillo, Bauer, \& Sanchez., 2001). Some researchers have shown that service recovery is related to customer's prior experience that is considered a problem (Singh, 1990; Tax et al., 1998; Tax \& Brown, 1998). According to Tax et al. (1998) customer personality can affect justice perception in determining procedural and interpersonal in determining the decision. The research result from Cronin and Taylor (1994; Ostrom \& Iacobucci., 1995) explain that customer will update or modify their satisfaction assessment after they interact with service providers. In every visit, customers will continually update their expectations as they combine with the new information they receive (Tax et al., 1998). This behaviour explains that customers' prior experience will shape their expectation. Every customer has an inherent expectation through the services ordered and has the potential for dissatisfaction. Dissatisfaction behaviour motivates customers to complain about services that are not in line with their expectation. Tax et al. (1998) finds that the positive evaluation is a prove that three dimensions of justice are important aspects that needs to be considered, which is distributive, procedural, and interactional justice in the complaint handling. Binter (1990) states that if the customer assesses the whole of the relationship with the company or product with the provisions (procedures), then the prior experience can identify the component from the services provided by the company.

H2: Customer's prior experience can provide a sense of interactional justice in the process of service recovery.

\section{Moderation of Customer Personality in the Service Recovery}

Customer personality is a whole combination of feature characteristics of nature that causes humans to be naturally unique (Lin, 2010). Personality differences between everyone affect the individual behaviour in overcoming the situation and condition that are less supportive. A stable personality trait 
can persist and easily influence people to behave consistently in different situations (Greeberg \& Baron, 2000). Furthermore, individual differences tend to be used to influence their environment. When a person acts to influence others either it is successful or not, the individual has used social influence on others. Some personality researches in justice research have recognized various personality traits and agrees that the traits that make up one's personality can be organized in a hierarchy as occurs in the five major personality models. George and Joners (2002)placed five common personality traits starting from the top of the hierarchy, which are: extroversion, emotional stability, agreeableness, conscientiousness, andopenness to experience.Gibson, Ivancevich and Donney (1990) add that there is an influence of individual values in the process of service recovery strategy. The research result from Masnita (2011) states that service recovery is influenced by locus attribution in the type of failure and service recovery strategy. Khalifah (2004) also adds that the satisfaction gained by obtaining an effective failure recovery can be an accumulation of customer value.

H3: Customer Personality moderates the influence of Customer's Prior Experience toward Interactional Justice

H4: Customer Personality moderates the influence of Customer's Prior Experience toward Procedural Justice.

\section{Research method}

The approach of this research is a causality research, where research is done to look for explanation in the form of causal relationship (cause-effect) between several variables developed. The sample of this research is 300 respondents from customers who experience service failure and complain to the e-banking service provider in three state-owned banks namely Bank Branches Office of BRI, BTN, and BNI in Bandung Region, Cirebon, Kuningan, Indramayu, and Majalengka, West Java Province, Indonesia. This means that it can meet the minimum requirement of survey research that amounted to 100 respondents (Hair, et al, 2006; Muafi et al., 2017). The sampling technique in this research is using non-probability sampling, which is accidental sampling. Withdraw and dissemination of the questionnaire is done by giving close questionnaire to the customer directly, related to the failure of e-banking service problem in each region. This approach has previously been used in the previous research (Badawi, 2012; Del RíoLanza, et al., 2007). The measurement of variables in this research is adopting the measurement from; (1) Tax et al. (1998), Huang (2011) for customer experience variables (Prior Experience-PE), (2) Lind (2009) for customer personality variables (Customer personality- CL), and (3) Tax et al. (1998), Badawi (2012), Badawi, et al. (2017) for interactional justice (interactional justice -IJ) and procedural justice (Procedural justice - PJ). The measurement of variable is developed based on the perceptions of bank customers who experienced the failure of e-banking services. The scale technique that is used is Likert scale, ranging from 1 (strongly disagree) to 6 (strongly agree). The statistic technique is using Structural Equation Modeling (SEM) and AMOS 22. The validity and reliability test result are valid and reliable.

\section{Research result and discussion \\ Description of respondent}

Based on the result of the data, most respondents have male gender of 198 (66\%), age of respondents $>46$ years old of 127 (42,3\%); occupation of respondent is self-employed, which is $123(41 \%)$, education of respondents is bachelor, which is 155 (51.6\%). 


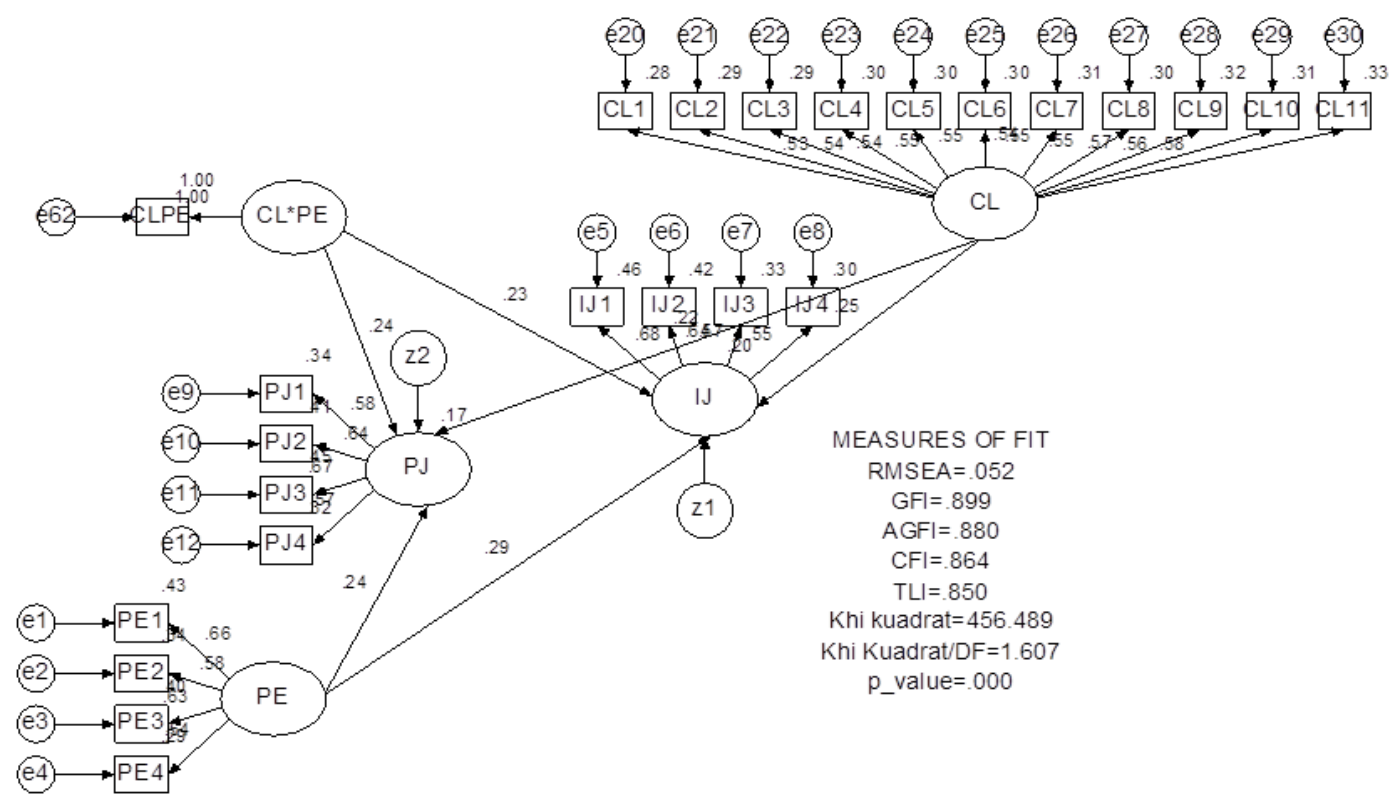

Figure 1. The Final Fit Model

\section{The Test of Goodness of fit model}

The test of structural models in general produces fit indices model. This shows that in the cut-off value, there are five goodness-of-fit with marginal value, which is GFI, AGFI, TLI, P-value and CFI. For evaluation of the goodness of fit from the structural model in Figure 1, RMSEA is used as absolute index, Cmin/DF, or $X^{2}$. This is in accordance with the suggestion proposed by Hair et al. (2006). The Root Mean Square Error of Approximation (RMSEA) value is 0,052 (less than 0,08), this indicates that the estimated model is good. Cmin/df or model $\mathrm{X}^{2}$ is $1,607<2,00$ with the probability value of 0,000 indicates that the model is not sensitive toward the number of samples and complexity; therefore, the structural model that test the causal relationship between construct or variable is a good structural model (Table 2).

Table 2. The Assessment of Fitness of Final Fit Model (Figure 1)

\begin{tabular}{|l|l|l|l|}
\hline Goodness of fit index & Cut off value & Model Result & Information \\
\hline Cmin/df & $<2,00$ & 1,607 & Fit \\
\hline RMSEA & $\leq 0.08$ & 0.052 & Fit \\
\hline GFI & $\geq 0.90$ & 0.899 & Moderate \\
\hline AGFI & $\geq 0.90$ & 0.880 & Moderate \\
\hline TLI & $\geq 0.95$ & 0.864 & Moderate \\
\hline CFI & $\geq 0.95$ & 0.850 & Moderate \\
\hline
\end{tabular}

Table 3 explain that $\mathrm{H} 1$ and $\mathrm{H} 2$ that is proposed are accepted. In order to understand the role of moderation of customer personality, it can be seen on Table 4 .

Table 3. The Influence of Dependent and Independent Variable in Structural Model

\begin{tabular}{|l|l|l|l|l|l|l|}
\hline Influence of the Variable & Standardized & CR & P & \\
\hline Prior Experience (PE) & $->$ & Interactional Justice (IJ) & 0.287 & 3.422 & $0.000^{*}$ & H1. Accepted \\
\hline Prior Experience (PE) & $->$ & Procedural Justice (PJ) & 0.245 & 2.895 & $0.000^{*}$ & H2. Accepted \\
\hline
\end{tabular}

*sign=alpha0.05 
Table 4. The Influence of Dependent and Independent Variable in Structural Model by Involving Moderation Variable and its Interaction

\begin{tabular}{|l|l|ll|l|l|l|l|}
\hline Influence of the Variable & Standardized & CR & P & \\
\hline $\begin{array}{l}\text { Customer Personality (CL) } \\
\text { Prior Experience (PE) }\end{array}$ & $\rightarrow$ & $\begin{array}{l}\text { Interactional Justice } \\
\text { (IJ) }\end{array}$ & 0.235 & 3.400 & 0.000 & $\begin{array}{l}\text { H3. } \\
\text { Accepted }\end{array}$ \\
\hline $\begin{array}{l}\text { Customer Personality (CL)* } \\
\text { Prior Experience (PE) }\end{array}$ & $->$ & $\begin{array}{l}\text { Procedural Justice } \\
(\mathrm{PJ})\end{array}$ & 0.237 & 3.701 & 0.004 & $\begin{array}{l}\text { H4. } \\
\text { Accepted }\end{array}$ \\
\hline
\end{tabular}

*sign=alpha 0.05

Table 4 explains that $\mathrm{H} 3$ and $\mathrm{H} 4$ are also accepted. This means that customer personality moderates (strengthen) the influence of prior experience toward procedural justice and interactional justice. The most powerful moderation from customer personality is the influence of prior experience toward procedural justice.

\section{Discussion}

The role of customer's prior experience is positively influenced the interactional justice toward ebanking service recovery. This research result is in accordance with the research result from Yuan and $\mathrm{Wu}$ (2008) which state that customer's prior experience in marketing has an influence toward satisfaction and loyalty through emotional and functional values. The more positive customer experiences on service recovery, the greater the sense of interactional justice. Interactional justice is manifested by giving empathy, attention to problem solving, and the willingness of the company to give explanations for complaints. In addition, another aspect of interactional justice is the communication style of employees (especially frontline employees) and managers can recover the service failure by having experience and knowledge to communicate with customers (Nadiri, 2016). Similarly, a study conducted by Sholeh (2014) explains that prior experience has a positive influence toward interactional justice. The research result explains that customer's prior experience can increase expectation of a sense of interactional justice in the process of service recovery.

A good service recovery process can eliminate customer anger, motivate customer, and promote customer retention by satisfying its customers (Etzel \& Silverman, 1981; Hart et al., 1990; Nadiri, 2016). This research result finds that prior experience has an influence toward perceived procedural justice. Procedural justice can be realized through the company's reasonable policies, criteria, and procedures to provide solution for the process of service recovery (Blodgett et al., 1997). Referring to the suggestion from Choi \& Choi (2014); Mattila, (2001) effective service recovery can be done with procedural justice based on the justice perception through the stages of failed service procedures and recovery processes. This research result also proves that the role of customer personality moderates the influence of customer's prior experience toward interactional justice and procedural justice. This finding is consistent with the research result from Masnita (2011) which states that service recovery is influenced by locus attribution in the type of failure and service recovery strategy. Khalifah (2004) states that satisfaction gained by obtaining an effective failure recovery can be an accumulation of customer value. The empirical result from Sholeh (2014) shows that personality strengthen the relationship of prior experience toward perceived procedural justice. It is true that one's perception of justice is not the only thing that influences the decision to demand justice for the service recovery. However, personality also plays a role between customer's prior experiences with the perceived justice of service recovery. It is based on the finding that personality has a role as an overall temperament, disposition, or interpersonal characteristic (Hogan., Hogan, \& Roberts., 1996).

An interesting finding from this research is that customer personality strengthens the influence of prior experience toward procedural justice than interactional justice. This indicates that the type of customer personality is more expecting from prior experience in procedural justice such as procedure speed, procedure flexibility, procedure policy, and adequate procedure. On the other hand, without any moderation of personality role, customer's prior experience is more concerned with interactional justice. Either it is admitted or not, service failure is something that cannot be avoided. Therefore, banks should try to do their best to eliminate or minimize the occurrence of service failure where there is an intense competition. It is important for banks manager to monitor the service quality provided, train employees 
regularly to provide a better service, and set up a work standard. This may be some of the actions that can be accepted and used by the management to reduce failures, especially on procedural and interactional justice. Managers should treat their customers as individuals and find solutions that customers want.

\section{Conclusion}

This research result proves that customer's prior experience can improve interactional and procedural justice in the e-banking service recovery in West Java, Indonesia. This research result also proves that the role of customer personality strengthens the influence of customer's prior experience toward interactional justice and procedural justice. The implication of this research is in order to respond to the development of highly competitive market, and the determinant factors of the competition are done by establishing and maintaining good relationships with customers (Chidambaram \& Ramachandra, 2012). The effective service recovery efforts from banks have a quite positive effect on the prior experience on interactional and procedural justice relationship as problem-solving solutions to service failures (Makdessian, 2004). Through an effective service recovery, managers are not only reducing the number of dissatisfied customers, but also increasing the number of satisfied customers, which will lead to the improvement of service performance and positive WOM communication.

This research result also proves that customer personality can strengthen the influence of prior experience toward perceived interactional and procedural justice. This could provide a suggestion for the bank that customer personality is important to be studied and managed properly as bank recovery strategy, and it is expected to have positive post-purchase behavior as a result (Nadir 2016). Service recovery in bank financial services is an important function of service delivery strategy. It is known that this sector is related with investment and public capital. With the existence of advanced technologies such as e-banking, mobile banking, and ATM services, the number of service failure can increase, and service recovery plays an important role in bank financial services. This research result shows that customer personality can moderate customer's prior experience toward interactional and procedural justice. This research result provides a picture that customer's prior experience can be used as a reference in evaluating each service offered to customers. In addition, the role of customer personality is important to encourage customer's prior experience to provide justice to the process of service recovery (Li, 2011), especially for banking service industry, because it is very vulnerable to service failure (Chebat et al., 2010). Therefore, it is important for e-banking service manager to develop appropriate strategies that will lead to an effective service recover that will be felt fairly among customers.

\section{Research Limitation and Future Research}

Further research is required to integrate the finding into the theory, since the finding application is limited by the scope and other factors that can limit the generalization and instruction for further research. First: using the data from one ATM complaint in e-banking to test the framework using the sample from the same population. Second: banking service industries are chosen for empirical studies. Therefore, it is impossible to say that this research result can be generalized for all service sectors. Third: cross section survey in service failure experience bring out a biased and inaccurate memory (Awa, et al, 2016), so it requires a specific stages of customers' prior experience as an alternative for further studies. Further studies can also test similar model that include commitment that reflects service recovery effectiveness. This research model can be tested in other services sector to analyze customers' perceived justice and customers' intention that vary in the service sectors. This research does not use in-depth interview and scenario-based experience to analyze the causal relationship.

\section{References}

Andreassen, T. W. (2000). Antecedents to Satisfaction with Service Recovery.The European Journal of Marketing, Vol. 34, No. $1 / 2$, pp. 156-175.

Aquino, K., Lewis, M.U., and Bradfield, M. (1999). Justice constructs, negative affectivity, and employee deviance: A proposed model and empirical test, Journal of Organizational Behavior 20, pp. 1073-1091.

Awa. O.H., Ukoha. O., and Ogwo. E. O. (2016). Correlates of justice encounter in service recovery and word-of-mouth publicity. Cogent Business \& Management.3: 1179613

Badawi. (2012). Justice and Customer Emotion's Effect on Complaint Handling Satisfaction: A Survey on Complaint Attitude Handling, "International Journal of Innovation, Management and Technology", 3(5). 
Badawi. Tjahjono H.K., and Muafi. (2017). The Role of Corporate Reputation Moderation of Banking Services, Polish Journal of Management Studies. Vol.15 No.1

Barrick, M. R., Parks, L., and Mount, M. K. (2005). Self-monitoring as a moderator of the relationships between personality traits and performance. Personnel Psychology, 58, 745-767

Bauer, T. N., Morrison E.W., and Callister, R. R. (1998). Organizational socialization: A review and directions for future research. Research in Personnel and Human Resources Management, 16, 149-214.

Berry, L. L., and Parasuraman, A. (1991). Marketing Services. New York, NY: The Free Press.

Bies, R. J., \&Moag, J. S. (1986). Interactional Justice: Communication Criteria for Fairness. In Lewicki, L. H., Sheppard, B. H., \&Bazerman, M. H. (ed). Research on Negotiation in Organizations, Vol. 1, pp. 43-55. Greenwich, CT: JAI Press

Bitner, M. J. (1990). Evaluating Service Encounters: The Effects of Physical Surroundings and Employee Responses. Journal of Marketing, Vol. 54 (April), pp. 69-82

Bitner, M., Booms, B., and Tetreault, M. (1990). “The Service Encounter: Diagnosing Favourable and Unfavourable Incidents", Journal of Marketing, Vol. 54, January, pp. 71-84

Blodgett J.G., Hill D.J., and Tax S.S. (1997). The Effects of Distributive, Procedural, and Interactional Justice on PostComplaint Behavior, "Journal of Retailing", 73(2).

Blodgett, J.G.D., and Tax. J.H.S. (1993). The effects of distributive and interactional justice on complainants' repatronage intentions and negative word-of-mouth intentions. Journal of Consumer Satisfaction, Dissatisfaction and Complaining Behavior. 6.-100-110

Chebat, J. C., Amor, K. B., and Davidow, M. (2010). Why bank customers dissatisfied with service recovery remain loyal: An affect control theory approach. Journal of Marketing Trends, 1, 77-83.

Chelminski, P., and Coulter, R.A. (2011). An examination of consumer advocacy and complaining behavior in the context of service failure, Journal of Services Marketing, 25 (5), pp. 361-370.

Chidambaram, V., and Ramachandran, A. (2012). A review of customer satisfaction towards service quality of banking sector. Social and Management Sciences, V2(2), 71-79

Choi, B. \&Choi, B.J. (2014). The effects of perceived service recovery justice on customer affection, loyalty, and wordof-mouth, European Journal of Marketing, 48 (1/2), pp. 108-131.

Clemmer, E. C., and Schneider, B. (1996). Fair Service. Advances in Services Marketing and Management. Vol. 5, pp. 109-126

Colquitt, J. A. (2001). On the Dimensionality of Organizational Justice: A Construct Validation of a Measure. Journal of Applied Psychology, Vol. 86, pp. 386-400.

Colquitt, J. A., Scott A, B. A., Judge, T.A., and Shaw, J.C. (2006). Organizational Behavior and Human Decision Processes. 100. 110-127

Cronin, J.J., and Taylor, S.A. (1994). "SERVPERF versus SERVQUAL: reconciling performance based and perceptionsminus-expectations measurement of service quality", Journal of Marketing, Vol. 58 No. 1, January, pp. 125-31.

Del Rio-Lanza, AB., Vazquez-Casielles, R., Diaz-Martin, A. M. (2009). Satisfaction with service recovery: Perceived justice and emotional responses. Journal of Business Research, 62(8): 775-781

Elovainio, M., Kivimaki, M., Vahtera, J., Keltikangas-Jarvinen, L., and Virtanen, M. (2003). Sleeping problems and health habits as mediators between organizational justice and health. Health Psychology, 22, 287-293

Engel, R. D., Blackwell, J.F., and Miniard, P.W. (1993). Consumer Behavior, 7th. ed., NY: Dryden Press

Etzel, M. J., and Silverman, B. I. (1981). A managerial perspective on directions for retail customer dissatisfaction research. Journal of Retailing, 57, 124-136.

Fornell, C., and Wernerfelt, B. (1988), A model for customer complaint management, Marketing Science, Vol. 7 No. 3 , pp. 287-98.

George. J. M., and Joners. G.R. (2002). Understanding and Managing Organizational Behavior. Prentice Hall, 2002 Business \& Economics - 728 pages

Gibson.J. L, Ivancevich, J.M., and Donney. J.H. (1990). Organizations: conduct, structure, process Behavior. Dallas: Business Publication, Inc

Goodwin, C., and Ross, I. (1992). Consumer Responses to Service Failures: Influence of Procedural and Interactional Fairness Perception. Journal of Business Research, Vol. 25 No. 2, pp. 149-63.

Gountas, J., and Gountas, S. (2007). Personality orientations, emotional states, customer satisfaction, and intention to repurchase, Journal of Business Research, Volume 60, Issue 1 Pages 72-75

Greenberg, J., and Baron, R. A. (2000) Behavior in Organizations: Managing the Human Side of Work, Seventh Edition. New Jersey: Prentice Hall International, Inc

Hair, J. F., Anderson, R. E., Tathan, R. L., and Black, W. C. 2006. Multivariate Data Analysis, Seventh Edition. New Jersey, NJ: Prentice Hall International

Hart, C. W. L., Heskett, J. L., \& Sasser Jr, W. E. (1990). The profitable art of service recovery. Harvard Business Review, $68,148-156$. 
Hess, T. M., Auman, C., Colcombe, S. J., and Rahhal, T. A. (2003). The impact of stereotype threat of age difference in memory performance. J. Gerontol. B Psychol. Sci. Soc. Sci. 58, P3-P11. doi: 10.1093/geronb/58.1. P3

Hogan, J. E., Lemon, K. N., and Libai, B. (2003). What is the true value of a lost customer? Journal of Service Research, 5, 196-208.

Hogan, R., Hogan, J., and Roberts, B. W. (1996). Personality measurement and employment decisions: Questions and answers. American Psychologist, 51, 469-477.

Huang, M. H. (2011). Re-examing the Effect of Service Recovery : The Moderating Role of Brand Equity. Journal of Services Marketing, Vol. 25, No. 7, pp. 509-516.

Jani, D., and Han, H. (2015). Influence of environmental stimuli on hotel customer emotional loyalty response: Testing the moderating effect of the Big Five personality factors', International Journal of Hospitality Management, 44: 48-57

Judge.T.A., and Martocchio, J. J. (1995). The Role of Fairness Orientation and Supervisor Attributions, Absence Disciplinary Decisions. Journal of Business and Psychology Volume 10, No. 1

Kelley, S., and M. Davis. (1994). Antecedents to customer expectations for service recovery, Journal of International Consumer Marketing 8(2) 59-76.

Khalifah, A.S. (2004). "Customer value: a review of recent literature and an integrative configuration." Management Decision, 42(5), 645-666.

Lewin, K. (1951). Field theory in social science; selected theoretical papers. D. Cartwright (ed.). New York: Harper \& Row

Li, W. (2011). Study of Service Recovery of Travel Agency Based on Customer Satisfaction: An Empirical Investigation. International Conference on Economics and Finance Research - IPEDR, Vol. 4, pp. 545-548.

Lin, W. B. (2009). A Study of Relations among Service Quality Differences, Post-purchase Behavior Intentions with Personality Traits, and Service Recovery Strategy as Intervening Variables.International Journal of Commerce and Management, Vol. 19, No. 2, pp. 137-157

Lin, W. B. (2009). A Study of Relations among Service Quality Differences, Post-purchase Behavior Intentions with Personality Traits, and Service Recovery Strategy as Intervening Variables. International Journal of Commerce and Management, Vol. 19, No. 2, pp. 137-157.

Lin. L.Y. (2010) "The relationship of consumer personality trait, brand personality and brand loyalty: an empirical study of toys and video games buyers", Journal of Product E Brand Management, Vol. 19 Issue: 1, pp. $4-17$

Lind, E.A. (2001). Fairness heuristic theory: Justice judgments as pivotal cognitions in organizational relations. In J. Greenberg \& R. Cropanzano (Eds.), Advances in

Makdessian, L. (2004). Consumers' reactions to service failures: The intervening roles of anger and gender. Canada: Concordia University

Mattila, A., and Wirtz, J. (2006). “Arousal expectations and service evaluations”, International Journal of Service Industry Management, Vol. 17 No. 3, pp. 229-44.

Mattila. A.S. (2001) "The effectiveness of service recovery in a multi-industry setting", Journal of Services Marketing, Vol. 15 Issue: 7, pp.583-596.

McDougall, G.H.G., and Levesque. T (2000), Customer Satisfaction with Services: Putting Perceived Value into The Equation, Journal of Services Marketing, Vol. 14 No. 5, pp 392-410.

Mossberg, L. (2007). A marketing approach to tourist experience. Scandinavian Journal of Hospitality and Tourism, 7 (1), 59-74.

Muafi., Suwitho., Purwohandoko., and Salsabil, I. (2017). Human Capital in Islamic Bank and Its Effect on the Improvement of Healthy Organization and Employee Performance, International Journal for Quality Research, 11 (4), p. 849-868.

Nadiri.H. (2016). Diagnosing the impact of retail bank customers' perceived justice on their service recovery satisfaction and post-purchase behaviours: an empirical study in financial center of middle east, Economic Research-EkonomskaIstraživanja, 29:1

Nikbin D., Ismail I., and Marimuthu M. (2010). Perceived Justice in Service Recovery and Recovery Satisfaction: The Mediating Role of Trust, "World Applied Sciences Journal”, 10

Nikolaou, I., and Robertson, I. T. (2001). "The Five-Factor Model of personality and work behavior in Greece", European Journal of Work and Organizational Psychology, vol. 10, no. 2, pp. 161 - 186.

Oh, H., and Parks, S. (1997). Customer Satisfaction and Service Quality: A Critical Review of the Literature and Research Implications for the Hospitality Industry. Hospitality Education Research Journal, Vol. 20, No. 3, pp. 3464.

Oh, H., Fiore, A., and Jeoung, M. (2007). Measuring experience economy concepts: Tourism applications. Journal of Travel Research, 46, 119-132 
Organ, D. W. (1990). “The motivational basis of organizational citizenship behavior”, in: Staw, B. M. \& Cummings, L. L. (Eds.) Research in organizational behavior, JAI Press, Greenwich, CT., Vol. 12, PP.43-72.

Ostrom, A., and Iacobucci, D. (1995). Consumer trade-offs and the evaluation of services. Journal of Marketing, 59(1), 17-28

Parasuraman, A., Zeithaml, V.A., and Berry, L.L. (1985). “A conceptual model of service quality and implications for future research", Journal of Marketing, Vol. 49, Fall, pp. 41-50

Parasuraman, A., Zeithaml, V.A., and Berry, L.L. (1996). "The behavior consequences of service quality", Journal of Marketing, Vol. 60, pp. 31-46

Ryan. A. M., and Chan, D. (1999). Self-serving biases in perceptions of fairness and the psychology licensing examination. Paper presented at the 14"' annual conference of the Society for Industrial and Organizational Psychology. Atlanta, GA

Shin. H., Casidy. R., and Mattila. A.S., (2018) Service Recovery, Justice Perception, and Forgiveness: The Other Customers Perspectives. Services Marketing Quarterly. 39 NO. 1.1-21

Singh, J. (1990). Voice, Exit, and negative Word of Mouth Behavior, An Investigation. Across Three Service Categories, Journal of the academy of Marketing Science 18. 1-15

Singh, J. (1990a). A Typology of Consumer Dissatisfaction Response Styles. Complaint Intentions and Behavior: Definitional and Taxonomical Issues. Journal of Marketing, Vol. 52 (1), p. 93-107.

Singh, J., and Wilkes, R.E. (1996). "When consumers complain: a path analysis of the key antecedents of consumer complain response estimates", Journal of the Academy of Marketing Science, Vol. 24, pp. 350-65.

Soleh H., (2014). The Role of the Personality of Customers and Reputation the Company as the Restoration of Services on the model of moderation variable: in the Automotive Industry in Indonesia, "Business and Entrepreneurial Review", 14(1) October

Tax, S. S., Brown, W. W., and Chandrashekaran, M. (1998). Customer evaluations of service complaint experiences: Implications for relationship marketing. Journal of Marketing, 62, 60-76.

Tax, S.S., and Brown, S.W. (1998). Recovering and learning from service failure. Sloan Management Review 40, 75-88.

Todd A. M., and Olver. J, M (1997). "I Can't Get No Satisfaction:" The Impact of Personality and Emotion on Post purchase Processes," Psychology E Marketing, 14 (4), 379-93

Truxillo, D.M., Bauer, T.N., and Sanchez, R.J. (2001). Multiple dimensions of procedural justice: Longitudinal effects on selection system fairness and test-taking self-efficacy. International Journal of Selection and Assessment, 9, 336349.

Tyler, T. R. (1987). Conditions leading to value-expressive effects in judgments of procedural justice: A test of four models. Journal of Personality and Social Psychology, (2), 333-344.

Tyler, T. R., and Bies, R. J. (1990). Beyond Formal Procedures: The Interpersonal Context of Procedural Justice. In J. Carroll (Ed.), Applied Social Psychology and Organizational Settings, pp. 77-98. Hillsdale, NJ: L. Erlbaum Associates.

Van den Bos, K. (2001). Uncertainty management: The influence of uncertainty salience on reactions to perceived procedural fairness. Journal of Personality and Social Psychology, 80, 931-941.

Woodruff, R. B., Ernest R. C., and Roger L. J. (1983). Modeling Consumer Satisfaction Processes Using Experience Based Norms. Journal of Marketing Research, Vol. 20 (August), pp. 296-304.

Yuan, Y.-H.E., and Wu, C.K. (2008). Relationships among experiential marketing, experiential value, and customer satisfaction, Journal of Hospitality $\mathcal{E}$ Tourism Research, 32(3), 387-410

Zeithaml, V., Parasuraman, A., and Berry, L. L. (1990). Deliverying Quality Service: Balancing Perceptions and Expectations.New York, NY : The Free Press. 